\title{
Toxicity of Diclofenac and its Biotransformation by Raoultella sp. DD4
}

\author{
Dorota Domaradzka, Urszula Guzik, Katarzyna Hupert-Kocurek, \\ Danuta Wojcieszyńska*
}

Department of Biochemistry, Faculty of Biology and Environmental Protection, University of Silesia in Katowice, Jagiellońska 28, 40-032 Katowice, Poland

Received: 8 March 2016

Accepted: 14 April 2016

\begin{abstract}
In recent years the increased consumption of diclofenac, a biologically active compound that is toxic to organisms and persistent to biodegradation, has resulted in its presence in the environment. This is the first report on the biotransformation of diclofenac by a pure bacterial strain, Raoultella sp. DD4, which is able to transform $0.6 \mathrm{mg} / \mathrm{L}$ of diclofenac in 28 days. Additionally, strain DD4 is more resistant to diclofenac than other tested organisms. The estimated value for EC50 for this strain is $1.95 \mathrm{~g} / \mathrm{L}$. This is approximately five-fold higher than the value of microbial toxic concentration $\mathrm{MTC}_{\text {avg }}(0.416 \mathrm{~g} / \mathrm{L})$. Moreover, genotoxicity studies have indicated that diclofenac is not a mutagenic compound.
\end{abstract}

Keywords: biotransformation, diclofenac, toxicity, Raoultella

\section{Introduction}

The global consumption of non-steroidal antiinflammatory drugs has dramatically increased in recent years. Although such drugs can improve quality of life, they also contribute to increasing environmental pollution. Among the non-steroidal anti-inflammatory drugs, diclofenac has been added to a list of 33 pollutants that are monitored and controlled in European Union surface water [1-2]. Diclofenac is not completely metabolized in organisms and it is discharged as a contaminant to wastewater treatment plants. Because most wastewater treatment plants are unable to remove diclofenac, it has been detected in groundwater, surface water, and wastewater effluents, as well as in drinking water at concentrations ranging between $\mathrm{ng} / \mathrm{L}$ and $\mu \mathrm{g} / \mathrm{L}$ [2-4].

*e-mail: danuta.wojcieszynska@us.edu.pl
Although concentrations of diclofenac in the environment do not cause acute toxicity, chronic toxicity is potentially possible. For example, in some studies histopathological effects on the liver, kidney, and gills of trout at concentrations of 1.0-5.0 $\mu \mathrm{g} / \mathrm{L}$ have been observed [2-3]. Additionally, the high octanol-water partition coefficient of diclofenac may cause bioaccumulation of this drug in fish or other organisms, and may be a subsequent potential secondary poison in the food chain [3].

Diclofenac undergoes decomposition by physicochemical factors and it is generally resistant to biological treatment [5]. However, physico-chemical transformation leads to the formation of potentially harmful byproducts while the biological techniques are safer and more cost-effective. Unfortunately, little is known about microorganisms able to degrade or biotransform diclofenac. Trametes versicolor and the white rot fungi Phanerochaete chrysosporium and Phanerochaete sordida were described as being able to biotransform diclofenac. 
During these processes hydroxylated derivatives were found. This suggests that hydroxylating enzymes such as laccase or cytochrome P-450 are probably engaged in diclofenac biotransformation [6-9]. Bacteria able to degrade this compound are still unknown.

In light of the above-mentioned facts it is very important to study the microbiological degradation of diclofenac and its impact on microorganisms. Therefore, the aim of our work was to investigate the toxicity of diclofenac to different microorganisms, and the ability of Raoultella sp. DD4 to degrade diclofenac.

\section{Materials and Methods}

$$
\text { Phylogenetic Analysis }
$$

Bacterial DNA was isolated from pure culture using the DNA commercial kit (GenElute Bacterial Genomic DNA Kit, Sigma-Aldrich). 16S rRNA gene amplification, sequencing and sequence analysis were carried out as described by Guzik et al. [10]. The 16S rRNA gene sequence determined in this study has been deposited in the GeneBank database under accession number KU684448.

\section{Morphological, Physiological, and Biochemical Characterization of the DD4 Strain}

The DD4 strain was phenotypically and biochemically characterized using standard techniques (Gram staining, colony shape, size and colour on nutrient agar plate, etc.), according to Bergey's Manual of Determinative Bacteriology [11]. Additional biochemical and physiological characteristics were determined using the API 20NE system (BioMerieux, Lyon, France).

\section{Diclofenac Degradation Experiment}

Raoultella sp. DD4 was routinely cultivated in the nutrient broth at $30^{\circ} \mathrm{C}$ and $130 \mathrm{rpm}$ for 24 hours. After this, cells were harvested by centrifugation $\left(5,000 \times \mathrm{g}\right.$ at $4^{\circ} \mathrm{C}$ for $15 \mathrm{~min}$ ), washed with a fresh sterile medium, and used as inoculum.

Degradation of diclofenac was performed in $500 \mathrm{ml}$ Erlenmeyer flasks containing $250 \mathrm{ml}$ of a mineral salt medium [12] and inoculated with cells to a final optical density of about 1.0 at $\lambda=600 \mathrm{~nm}$ (OD600). Diclofenac was added to obtain a final concentration of $6 \mathrm{mg} / \mathrm{L}$, and all cultures were incubated with shaking at $30^{\circ} \mathrm{C}$ for 28 days. Chromatographic analyses of the culture fluid and measurements of culture growth were carried out every seven days. All cultures were grown in triplicate.

Additionally, two control cultures $(250 \mathrm{~mL})$ were prepared: an uninoculated control consisting only of the mineral salt medium (abiotic degradation control), and a heat-killed control consisting of bacterial cells destroyed by autoclaving (adsorption onto biomass control). The optical density of the heat-killed control was the same as for the examined cultures.

\section{Determination of Substrate Concentration}

The concentration of diclofenac was determined with the HPLC technique using the Merck Hitachi HPLC reversed-phase chromatograph equipped with an Ascentis Express C18 HPLC Column (100 x 4.6mm), an OptiSolw EXP pre-column, and a UV/VIS DAD detector. The mobile phase composed of acetonitrile, $1 \%$ acetic acid, and methanol $(50: 30: 20 \mathrm{v} / \mathrm{v})$ at a flow rate of $1 \mathrm{~mL} / \mathrm{min}$ was used during analysis of the diclofenac concentration. The detection wavelength was set at $276 \mathrm{~nm}$. Diclofenac in supernatant was identified by comparing the HPLC retention time and UV-visible spectra with that of the external standard.

\section{Bacterial Growth Inhibition Test}

To determine the inhibitory effect of diclofenac on bacterial growth, a pure culture of Raoultella sp. DD4 was grown in a nutrient broth supplemented with diclofenac in a concentration range of $0-3.0 \mathrm{~g} / \mathrm{L}$. The initial optical density of each culture was $0.1\left(\mathrm{OD}_{600}\right)$. After 24 hours of incubation with shaking at $30^{\circ} \mathrm{C}$, the optical density of the cultures was measured. The $\mathrm{EC}_{50}$ value was estimated using GraphPad PRISM 6.05 software.

\section{Toxicity Bioassays}

We used the MARA test to assess the acute toxicity of diclofenac toward various microorganisms [13]. The MTC value was calculated according to the formula:

$$
\mathrm{MTC}=c_{\min } \times d\left(\frac{P_{\mathrm{tot}}}{P_{\mathrm{o}}}\right)-1
$$

... where $c_{\min }$ is the lowest concentration in the gradient, $P_{\text {o }}$ is pellet size in the control, $d$ is dilution factor, and $P_{\text {tot }}{ }^{\circ}$ is sum of all the pellets sizes across the concentration gradient [13-15].

Ames MPF tests (Xenometrix) were performed with Salmonella typhimurium TA98 and Salmonella typhimurium TA100 according to the manufacturer's recommendations. Ten $\mathrm{mL}$ of the growth medium were inoculated with $10 \mu \mathrm{l}$ of refrozen bacterial strains and incubated for 16 hours at $37^{\circ} \mathrm{C}$ with shaking at $250 \mathrm{rpm}$ in the presence of $50 \mu \mathrm{g} / \mathrm{mL}$ ampicillin until culture density reached $>2.0\left(\mathrm{OD}_{600}\right)$. Next, the cultures were diluted 10fold in the exposure medium, and $240 \mu \mathrm{L}$ of the mixture was introduced into every well of the 24 -well plate.

Simultaneously, an appropriate volume of $600 \mathrm{mg} / \mathrm{L}$ diclofenac stock solution was introduced into the wells to obtain the final concentrations of $18.75,37.50,75,150$, 300 , and $600 \mathrm{mg} / \mathrm{L}$. Diluted inocula of bacterial strains were negative controls. The positive controls comprised the diluted inoculum and $0.1 \mu \mathrm{g} / \mathrm{mL}$ 4-nitroquinoline$\mathrm{N}$-oxide or $2.0 \mu \mathrm{g} / \mathrm{mL}$ 2-nitrofluorene as mutagens. The mutagenicity assays were also conducted in the presence of metabolic activation fraction S9 (rat liver microsomal fraction). The samples were prepared as described above, 


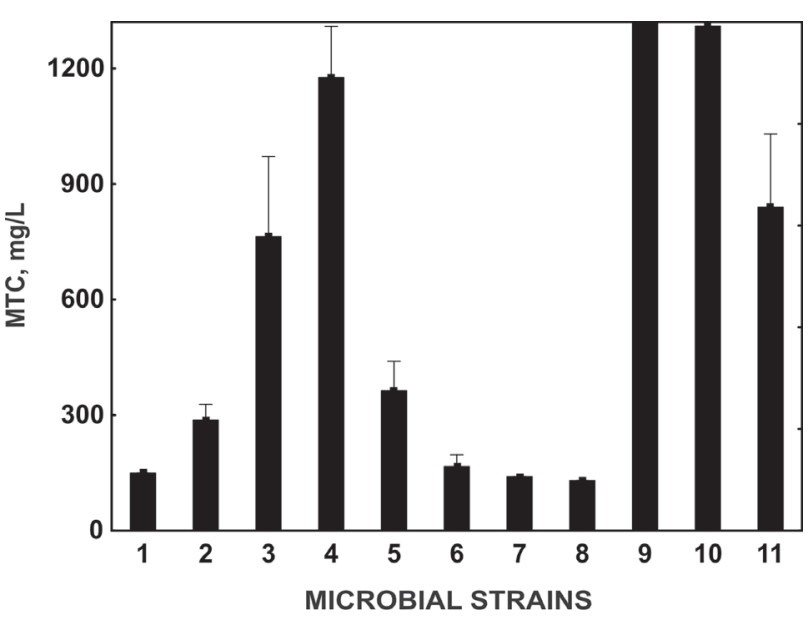

Fig. 1. Mean MTC values in the MARA test, with diclofenac exposure ranging between 180 and $1330 \mathrm{mg} / \mathrm{L}$. Microorganisms used in the MARA test: 1 - Microbacterium sp. G(+); 2 - Brevundimonas diminuta G(-); 3 - Citrobacter freudii G(-); 4 - Comamonas testosteroni G(-); 5 - Enterococcus casseliflavus $\mathrm{G}(+) ; 6$ - Delftia acidovorans $\mathrm{G}(-) ; 7$ - Kurthia gibsonii $\mathrm{G}(+)$; 8 - Staphylococcus warneri G(+); 9 - Pseudomonas aurantiaca G(-); 10 - Serratia rubidaea G(-); and 11 - Pichia anomala (yeast).

except that the microsomal fraction was further introduced into each well. Diluted inocula of bacterial strains were negative controls. The positive controls consisted of diluted inocula of bacteria, fraction $\mathrm{S} 9$, and 0.5 or $1.25 \mu \mathrm{g} / \mathrm{mL}$ 2-aminoanthracene for strains TA98 or TA100, respectively.

The 24-well plates were then incubated for 90 minutes at $37^{\circ} \mathrm{C}$ with shaking at $250 \mathrm{rpm}$, and the cultures were mixed with the indicator medium. Then, $50 \mu \mathrm{L}$ aliquots of each culture were replica plated into 48 wells of a 384well plate and incubated at $37^{\circ} \mathrm{C}$ for 48 hours. The number of positive wells out of 48 wells per replicate and per tested concentration of ibuprofen was compared with the number of spontaneous revertants obtained in the negative control section [16].

\section{Results and Discussion}

\section{Toxicity of Diclofenac}

Diclofenac is a biologically active compound. Therefore, this drug and products of its transformation in vertebrates and in the environment may increase ecological risk [17]. Knowledge concerning the impact of diclofenac on bacteria is limited. The EC50 values estimated by Ferrari et al. [18] in the Microtox test with Vibrio fischeri as a standard microorganism amounted to $11.454 \mathrm{mg} / \mathrm{L}$ of diclofenac. For cyanobacteria Synechococcus leopolensis the non-observed-effect concentration for diclofenac was $10 \mathrm{mg} / \mathrm{L}$, while the inhibition of growth of Grampositive and Gram-negative bacteria was observed at 50 to $100 \mathrm{mg} / \mathrm{L}$ [19]. Moreover, diclofenac influences the structural divergence of the bacterial population in active sludge and reduced bacterial diversity, leading to functional changes in active sludge wastewater treatment systems [20]. Because of this, it is especially important to investigate the effect of diclofenac on a pure bacteria strain able to degrade this drug.

To evaluate the acute toxicity of diclofenac in bacteria we used the MARA test, which was carried out with 10 bacterial strains and one yeast strain [13].

We observed different responses of the tested microorganisms. The most sensitive microorganism was Gram-positive Staphylococcus warneri (Fig. 1). The MTC for this strain was $130.00 \pm 0.0 \mathrm{mg} / \mathrm{L}$, whereas the most resistant strains were Pseudomonas aurantiaca and Serratia rubidaea (MTC above $1300 \mathrm{mg} / \mathrm{L}$ ). The mean value of microbial toxic concentration $\mathrm{MTC}_{\text {avg }}$ for diclofenac, which is the equivalent of $\mathrm{EC}_{50}$, was $416.67 \pm 5.77 \mathrm{mg} / \mathrm{L}$. According to EU Directive 93/67/EEC, substances with $\mathrm{EC}_{50}>100 \mathrm{mg} / \mathrm{L}$ are classified as nontoxic compounds to aquatic organisms [21-22].

We also examined the mutagenic potential of diclofenac. Table 1 presents a summary of the results of the Ames mutagenicity assay. In this test, two model organisms - Salmonella typhimurium TA98 and Salmonella typhimurium TA100 - were treated with diclofenac. We showed that diclofenac did not induce a significant dose-related increase in the number of revertant colonies in the tested strains either in the presence or absence of the metabolic activation system. According to U.S. Environmental Protection Agency and GenPharmTox guidelines (mutant frequency above two-fold greater than the control frequency obtained in the same experiment) indicates the potential mutagenic influence of the compound [23]. In our study, none of the results of the Ames test exceeded the critical value, 2.0.,

Table 1. Differential phenotypic characteristics of strain DD4.

\begin{tabular}{|c|c|c|c|}
\hline Characteristic & Results & Characteristic & Results \\
\hline Hydrolysis of esculin & + & Urease & - \\
\hline Hydrolysis of gelatin & - & $\begin{array}{l}\text { Indol } \\
\text { production }\end{array}$ & - \\
\hline Arginine dihydrolase & - & $\begin{array}{l}\text { Nitrate } \\
\text { reduction }\end{array}$ & + \\
\hline Glucose fermentation & + & & \\
\hline \multicolumn{4}{|c|}{ Assimilation of: } \\
\hline Glucose & + & Mannitol & + \\
\hline Arabinose & + & Maltose & + \\
\hline Mannose & + & Gluconate & + \\
\hline Malate & - & Caprate & - \\
\hline Citrate & - & Adipate & - \\
\hline Phenylacetate & - & $\begin{array}{c}\text { N-acetyl- } \\
\text { glucosamine }\end{array}$ & + \\
\hline
\end{tabular}

+ positive reaction, - negative reaction 


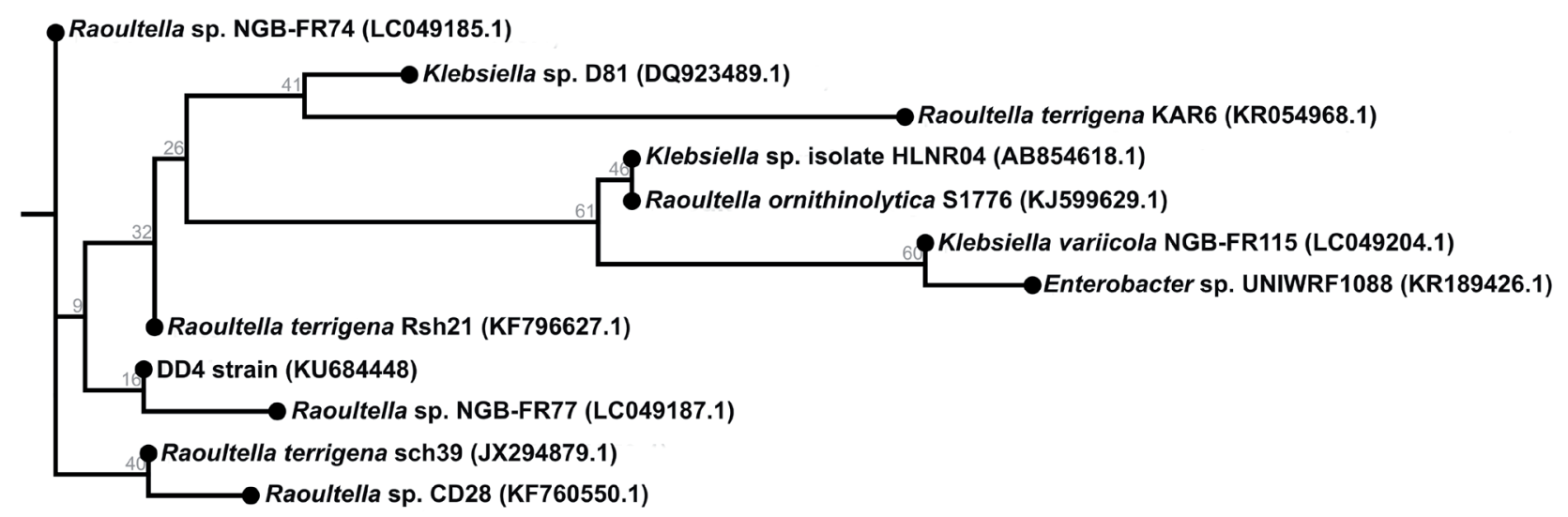

0.001

Fig. 2. Neighbour-joining tree showing the phylogenetic position of diclofenac-degrading bacterial strain DD4 and related species based on partial 16S rRNA gene sequences. The GenBank accession number for each microorganism used in the analysis is shown in parentheses after the species name. Bootstrap values (expressed as a percentage of 100 replicons) are shown at the branch.

and no mutagenic activity of diclofenac in Salmonella strains TA98 and TA100 was observed. These results are in accordance with the results of Philipose et al. [24].

Although the lack of a mutagenic effect and weak toxic effect of diclofenac on microorganisms was observed, the influence of diclofenac on processes in vertebrates is not excluded. For example, Chen et al. [2] showed that diclofenac altered the expression of genes important for the development of the cardiovascular and nervous systems in zebrafish.

Table 2. Mutagenic activity expressed as the mean and standard deviations of the number of revertants/plate in bacterial strains TA98 and TA100 treated with diclofenac, at various doses, without metabolic activation system or with metabolic activation system (S9).

\begin{tabular}{|c|c|c|c|c|c|c|}
\hline \multirow{3}{*}{$\begin{array}{l}\text { Dose level } \\
(\mathrm{mg} / \mathrm{L})\end{array}$} & \multicolumn{6}{|c|}{ Without metabolic activation system } \\
\hline & \multicolumn{3}{|c|}{ TA98 } & \multicolumn{3}{|c|}{ TA100 } \\
\hline & $\begin{array}{c}\text { Number of } \\
\text { revertants/plate }\end{array}$ & $\begin{array}{c}\text { Fold increase } \\
\text { (over baseline } 2.15 \text { ) }\end{array}$ & $\begin{array}{c}\text { t-test } \\
\mathrm{p} \text {-value }\end{array}$ & $\begin{array}{c}\text { Number of } \\
\text { revertants/plate }\end{array}$ & $\begin{array}{c}\text { Fold increase (over } \\
\text { baseline } 17.35 \text { ) }\end{array}$ & $\begin{array}{c}\text { t-test } \\
\mathrm{p} \text {-value }\end{array}$ \\
\hline 0 & $0.50 \pm 0.84$ & - & - & $14.83 \pm 3.06$ & - & - \\
\hline 18.75 & $2.33 \pm 2.52$ & 1.75 & 0.07 & $16.33 \pm 5.13$ & 0.91 & 0.30 \\
\hline 37.50 & $0.67 \pm 0.58$ & 0.50 & 0.38 & $14.67 \pm 2.08$ & 0.82 & 0.47 \\
\hline 75 & $1.33 \pm 0.58$ & 1.00 & 0.09 & $14.00 \pm 2.65$ & 0.78 & 0.35 \\
\hline 150 & $0.67 \pm 1.15$ & 0.50 & 0.40 & $10.00 \pm 5.57$ & 0.56 & 0.06 \\
\hline 300 & $1.67 \pm 1.15$ & 1.25 & 0.06 & $11.67 \pm 0.58$ & 0.65 & 0.06 \\
\hline 600 & $1.33 \pm 0.58$ & 1.00 & 0.09 & $12.00 \pm 4.00$ & 0.67 & 0.14 \\
\hline \multirow{3}{*}{$\begin{array}{l}\text { Dose level } \\
(\mathrm{mg} / \mathrm{L})\end{array}$} & \multicolumn{6}{|c|}{ With metabolic activation system } \\
\hline & \multicolumn{3}{|c|}{ TA98 } & \multicolumn{3}{|c|}{ TA100 } \\
\hline & $\begin{array}{l}\text { Number of } \\
\text { revertants/plate }\end{array}$ & $\begin{array}{l}\text { Fold increase (over } \\
\text { baseline } 3.00 \text { ) }\end{array}$ & $\begin{array}{c}\text { t-test } \\
\text { p-value }\end{array}$ & $\begin{array}{c}\text { Number of } \\
\text { revertants/plate }\end{array}$ & $\begin{array}{l}\text { Fold increase (over } \\
\text { baseline } 19.80 \text { ) }\end{array}$ & $\begin{array}{c}\mathrm{t} \text {-test } \\
\mathrm{p} \text {-value }\end{array}$ \\
\hline 0 & $1.17 \pm 0.75$ & - & - & $12.67 \pm 4.41$ & - & - \\
\hline 18.75 & $1.33 \pm 0.58$ & 0.69 & 0.37 & $12.00 \pm 6.24$ & 0.70 & 0.43 \\
\hline 37.50 & $1.33 \pm 0.58$ & 0.69 & 0.37 & $8.00 \pm 1.00$ & 0.47 & 0.06 \\
\hline 75 & $2.00 \pm 1.00$ & 1.04 & 0.10 & $9.00 \pm 1.00$ & 0.53 & 0.11 \\
\hline 150 & $0.67 \pm 1.15$ & 0.35 & 0.23 & $16.00 \pm 3.61$ & 0.94 & 0.15 \\
\hline 300 & $1.00 \pm 1.00$ & 0.52 & 0.39 & $12.33 \pm 2.08$ & 0.72 & 0.45 \\
\hline 600 & $1.00 \pm 1.00$ & 0.52 & 0.39 & $14.33 \pm 7.23$ & 0.84 & 0.34 \\
\hline
\end{tabular}




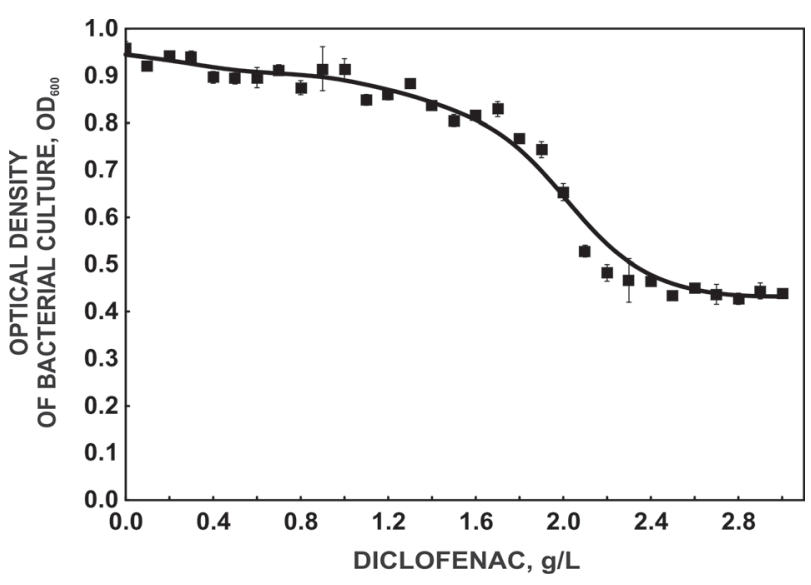

Fig. 3. Growth inhibition of Raoultella sp. DD4 in the presence of different diclofenac concentrations.

\section{Biotransformation Studies}

Until now, none of the bacterial strains have been isolated and characterized as diclofenac degraders.

The strain marked as DD4 is a Gram-negative rodshaped bacterium. Colonies of this strain were found to be circular, smooth, glossy, and cream-colored. The biochemical and physiological characteristics of strain DD4 are summarized in Table 2. Partial sequence analysis of the 16S rRNA gene allows for the classification of the isolate with $100 \%$ similarity as a member of the genus Raoultella (Fig. 2). In accordance with these data, the isolate DD4 was classified in the genus Raoultella and named Raoultella sp. DD4.

It has been reported that diclofenac in concentrations between 50 and $100 \mathrm{mg} / \mathrm{L}$ may be toxic to bacteria [25]. The $\mathrm{EC}_{50}$ of diclofenac obtained using Raoultella sp. DD4 grown in the nutrient broth supplemented with diclofenac in the concentration range from 0.0 to $3.0 \mathrm{~g} / \mathrm{L}$ was $1.95 \mathrm{~g} / \mathrm{L}$ (Fig. 3). The estimated value for $\mathrm{EC}_{50}$ is approximately five-fold higher than the value of microbial

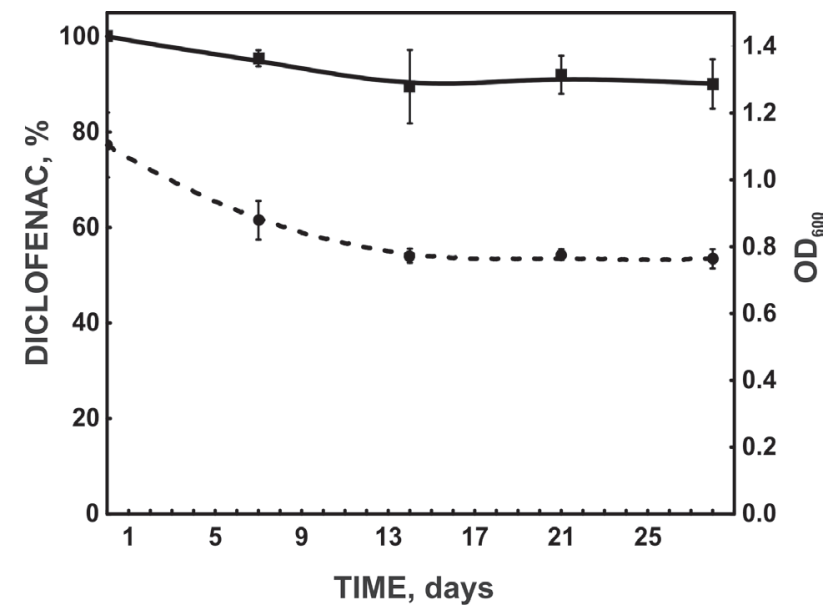

Fig. 4. Degradation of $6 \mathrm{mg} / \mathrm{L}$ diclofenac by Raoultella $\mathrm{sp}$. DD4 and changes of microbial biomass monitored as optical density at $600 \mathrm{~nm}$. toxic concentration $\mathrm{MTC}_{\text {avg. }}$. This indicates that the DD4 strain is especially resistant to diclofenac.

The resistance of the DD4 strain to diclofenac allowed for the supposition that this strain may be a good candidate for the biotransformation and/or biodegradation of this drug. The measurements of diclofenac in the uninoculated control (I) as well as in the heat-killed control (II) after 28 days of incubation revealed no changes in the concentration of the compound. This confirmed the lack of adsorption of diclofenac to the cell surface and chemical oxidation of this drug. Therefore, the ability of strain DD4 to degrade $6 \mathrm{mg} / \mathrm{L}$ of diclofenac was examined. As shown in Fig. 4, approximately 10\% $(600 \mu \mathrm{g} / \mathrm{L})$ of diclofenac was removed over 28 days. The degradation of diclofenac was accompanied by a decrease in the number of bacteria. As the used concentration of diclofenac is non-toxic for Raoultella sp. DD4, we may suppose that this compound is not a sufficient carbon and energy source for strain DD4. Until now, no data have been available on pure bacterial strains able to degrade or transform diclofenac. Only the mixed microbial cultures, derived mainly from activated sludge, were examined with a focus on the possibility of diclofenac decomposition in the concentration range $296 \mu \mathrm{g} / \mathrm{L}$ to $300 \mathrm{mg} / \mathrm{L}[4,26]$. The only strain that is able to utilize diclofenac with high efficiency in the pure culture is the fungus Phanerochaete sordida YK-624 [7].

\section{Conclusions}

Raoultella sp. DD4 is able to transform $0.6 \mathrm{mg} / \mathrm{L}$ of diclofenac over 28 days. However, diclofenac is not a sufficient carbon source for this strain. On the other hand, strain DD4 is uniquely resistant to diclofenac because the value of the $\mathrm{EC}_{50}$ for this strain is approximately five-fold higher than the value of the microbial toxic concentration $\mathrm{MTC}_{\text {avg }}$. Toxicity studies indicate the lack of a mutagenic effect of diclofenac on microorganisms, but it does not exclude the possibility that diclofenac may influence organisms in the environment.

\section{Acknowledgements}

This work was financed by the National Science Centre (Poland), granted on the basis of decision DEC2013/09/B/NZ9/00244.

\section{References}

1. European Commission. Brussels, 31.1.2012. Proposal for a Directive of the European Parliament and of the Council amending Directives 2000/60/EC and 2008/105/EC as regards priority substances in the field of water policy. COM(2011) 876 final.

2. CHEN J.B., GAO H.W., ZHANG Y.L., ZHANG Y., ZHOU X.F., LI CH.Q., GAO H.P. Developmental toxicity of diclofenac and elucidation of gene regulation in zebrafish (Danio rerio). Sci. Rep. 4, 4841, 2014. 
3. MEMMERT U., PEITHER A., BURRI R., WEBER K., SCHMIDT T., SUMPTER J.P., HARTMANNA. Diclofenac: new data on chronic Toxicity and bioconcentration in fish. Environ. Toxicol. Chem. 32, 442, 2013.

4. LANGENHOFF A., INDERFURTH N., VEUSKENS T., SCHRAA G., BLOKLAND M., KUJAWA-ROELEVELD K., RIJNAARTS H. Microbial removal of the pharmaceutical compounds ibuprofen and diclofenac from wastewater. BioMed Res. Int. Article ID 325806, 9 pages, 2013.

5. KOSJEK T., HEATH E., PEREZ S., PETROVIC M., BARCELO D. Metabolism studies of diclofenac and clofibirc acid in activated sludge bioreactor using liquid chromatography with quadrupole - time-of-flight mass spectrometry. J. Hydrol. 372, 109, 2009.

6. DOMARADZKA D., GUZIK U., WOJCIESZYŃSKA D. Biodegradation and biotransformation of polycyclic non-steroidal anti-inflammatory drugs. Rev. Environ. Sci. Biotechnol. 14, 229, 2015.

7. HATA T., KAWAI S., OKAMURA H., NISHIDA T. Removal of diclofenac and mefenamic acid by the white rot fungus Phanerochaete sordida YK-624 and identification of their metabolites after fungal transformation. Biodegradation 21, 681, 2010.

8. MARCO-URREA E., PEREZ-TRUJILlO M., CRUZMORATO C., CAMINAL G., VICENT T. Degradation of the drug sodium diclofenac by Trametes versicolor pellets and identification of some intermediates by NMR. J. Hazard. Mater. 176, 836, 2010.

9. RODARTE-MORALES A.I., FEIJOO G., MOREIRA M.T., LEMAJ.M. Biotransformation of three pharmaceutical active compounds by the fungus Phanerochaete chrysosporium in a fed batch stirred reactor under air and oxygen supply. Biodegradation 23, 145, 2012.

10. GUZIK U., GREŃ I., WOJCIESZYŃSKA D., ŁABUŻEK S. Isolation and characterization of a novel strain of Stenotrophomonas maltophilia possessing various dioxygenases for monocyclic hydrocarbon degradation. Braz. J. Microbiol. 40, 285, 2009.

11. HOLT J.G., KRIEG N.R., SNEATH P.H.A., STALEY J.T., WILLIAMS S.T. Bergey's manual of determinative bacteriology, Williams and Wilkins, USA, 1994.

12. GREŃ I., WOJCIESZYŃSKA D., GUZIK U., PERKOSZ M., HUPERT-KOCUREK K. Enhanced biotransformation of mononitrophenols by Stenotrophomonas malthophilia $\mathrm{KB} 2$ in the presence of aromatic compounds of plant origin. World J. Microbiol. Biotechnol. 26, 289, 2010.

13. BRONOWSKA M., STĘBOROWSKI R., BYSTRZEJEWSKA-PIOTROWSKA G. Estimation of the acute cesium toxicity by the microbial assay for risk assessment (MARA) test. Nukleonika 58, 481, 2013.

14. SIEROSLAWSKA A. Evaluation of usefulness of Microbial Assay for Risk Assessment (MARA) in the cyanobacterial toxicity estimation. Environ. Monit. Asses. 186, 4629, 2014.

15. WADHIA K. ISTA13 - international interlaboratory compa- rative evaluation of microbial assay for risk assessment (MARA). Environ. Toxicol. 23, 626, 2008.

16. FLÜCKIGER-ISLER S., BAUMEISTER M., BRAUN K., GERVAIS V., HASLER-NGUYEN N.H., REIMANN R., VAN GOMPEL J., WUNDERLICH H.G., ENGELHARDT G. Assessment of performance of the Ames II ${ }^{\mathrm{TM}}$ assay: a collaborative study with 19 coded compounds. Mutat. Res. 558, 181, 2004.

17. KRUGLOVA A., AHLGREN P., KORHONEN N., RANTANEN P., MIKOLA A., VAHALA R. Biodegradation of ibuprofen, diclofenac and carbamazepine in nitifying activated sludge under $12^{\circ} \mathrm{C}$ temperature comditions. Sci. Total Environ. 499, 394, 2014.

18. FERRARI B., PAXEUS N, GIUDICE R.L., POLLIO A., GARRIC J. Ecotoxicological impact of pharmaceuticals found in treated wastewaters: study of carbamazepine, clofibric acid, and diclofenac. Ecotox. Environ. Safe. 55, 359, 2003.

19. LAWRENCE J.R., SWERHONE G.D.W., TOPP E., KORBER D.R., NEU T.R., WASSENAAR L.I. Structural and functional responses of river biofilm communities to the nonsteroidal anti-inflammatory diclofenac. Environ. Toxicol. Chem. 26, 573, 2007.

20. CHERIK D., BENALI M., LOUHAB K. Occurrence, ecotoxicology, removal of diclofenac by adsorption on activated carbon and biodegradation and its effect on bacterial community: a review. World Sci. News 10, 116, 2015.

21. CLEUVERS M. Mixture toxicity of the anti-inflammatory drugs diclofenac, ibuprofen, naproxen, and acetylic acid. Ecotox. Environ. Safe. 59, 309, 2004.

22. ORTIZ DE GARCIA S.A., PINTO G.P., GARCIA-ENCINA P.A., IRUSTA-MATA R. Ecotoxicity and environmental risk assessment of pharmaceuticals and personal care products in aquatic environments and wastewater treatment plants. Ecotoxicology 23, 1517, 2014.

23. LAH B., ZINKO B., TISLER T., MARINSEK-LOGAR R. Genotoxicity detection in drinking water by Ames test, Zimmerman test and comet assay. Acta Chim. Slov. 52, 341, 2005.

24. PHILIPOSE B., SINGH R., KHAN K.A., GIRI A.K. Comparative mutagenic and genotoxic effects of three propionic acid derivatives ibuprofen, ketoprofen and naproxen. Mutat. Res. 393, 123, 1997.

25. GRÖNING J., HELD C., GARTEN C., CLAUSSNITZER U., KASCHABEK S.R., SCHLOMANN M. Transformation of diclofenac by the indigenous microflora of river sediments and identification of a major intermediate. Chemosphere $\mathbf{6 9}$, 509, 2007.

26. LEE H.J., LEE E., YOON S.H., CHANG H.R., KIM K., KWON J.H. Enzymatic and microbial transformation assays for the evaluation of the environmental fate of diclofenac and its metabolites. Chemosphere 87, 969, 2012. 